\title{
Anecic earthworms (Lumbricus terrestris) alleviate negative effects of extreme rainfall events on soil and plants in field mesocosms
}

\author{
Walter S. Andriuzzi • Mirjam M. Pulleman • \\ Olaf Schmidt • Jack H. Faber • Lijbert Brussaard
}

Received: 30 March 2015 / Accepted: 10 July 2015 / Published online: 25 July 2015

(C) The Author(s) 2015. This article is published with open access at Springerlink.com

\begin{abstract}
Background and aims Intense rains are becoming more frequent. By causing waterlogging, they may increase soil erosion and soil surface compaction, hamper seedling establishment, and reduce plant growth. Since anecic earthworms make vertical burrows that improve water infiltration, we hypothesised that they can counteract such disturbance.

Methods In a field experiment, intact soil mesocosms with ryegrass (Lolium multiflorum), with or without introduced adult Lumbricus terrestris, underwent either a precipitation regime with two intense rain events (36 mm, at beginning and end of spring), or a control regime with the same cumulative rainfall but no intense events. Short-term response of soil moisture and lagged response of plant growth were measured, and soil macroporosity was quantified.

Results Intense rains reduced ryegrass shoot biomass (by 16-21\% on average) only in the absence of earthworms. Waterlogging duration aboveground was not
\end{abstract}

Responsible Editor: Sven Marhan.

W. S. Andriuzzi $(\bowtie) \cdot$ M. M. Pulleman • L. Brussaard Department of Soil Quality, Wageningen University, P.O. Box 47, 6700 AA Wageningen, The Netherlands e-mail:ws.andriuzzi@gmail.com

W. S. Andriuzzi • O. Schmidt

UCD School of Agriculture and Food Science, University

College Dublin, Belfield, Dublin 4, Ireland

J. H. Faber

Alterra, Wageningen University and Research Centre, PO

Box 47, 6700 AA Wageningen, The Netherlands affected, whereas soil moisture contents after intense rainfall tended to drop faster with earthworms present. Continuous vertical macropores were found only in the mesocosms to which earthworms had been added. The number of such macropores was 2.4 times higher under the intense precipitation regime, despite similar earthworm survival.

Conclusions We found that anecic earthworms can offset negative effects of intense rainfall on plant growth aboveground. Underlying mechanisms, such as macropore formation and enhanced nutrient cycling, are discussed. We also observed that altered precipitation patterns can modify earthworm burrowing behaviour, as earthworms had produced more burrows under the intense regime.

Keywords Climate change $\cdot$ Lumbricidae Macropores $\cdot$ Ecosystem engineering $\cdot$ Precipitation . Waterlogging

\section{Introduction}

Climate change does not only entail shifts in long-term trends, but also variations in the frequency and magnitude of intense weather events (IPCC 2013). According to the Fifth Assessment Report of the Intergovernmental Panel on Climate Change (IPCC 2013), the chance of heavy rains and flooding is increasing globally, as precipitations will be "concentrated into more intense events, with longer periods of little precipitation in between". The ecological consequences of such events 
are more difficult to predict than those of gradual shifts in averages, but may be no less critical (Jentsch et al. 2007; Reyer et al. 2013). So far, drought has been given more attention than intense rainfall (Beier et al. 2012), but both can have major effects on soil and plants. Excessive water may cause anoxia in the rhizosphere and hinder nutrient uptake by plants (Sairam et al. 2008), which is especially detrimental to seedlings (Cannell et al. 1980). Waterlogging caused by excessive rain can decrease plant growth to the point of seriously reducing agricultural yields (Cannell et al. 1984; Rosenzweig et al. 2002). Common technical solutions, for instance artificial drains, are costly and often ineffective (Setter and Waters 2003). Moreover, the use of heavy agricultural machinery on wetter soils may cause soil compaction, making the soil even more prone to waterlogging (Batey 2009) and reducing soil workability and trafficability. However, soil organisms can improve the resistance and resilience of soil against disturbance, for instance by enhancing soil structure (Brussaard et al. 2007). It has therefore been suggested that agricultural practices that stimulate soil biodiversity, such as increased crop diversity, reduced tillage and continuous soil cover, could help mitigate the effects of climate change (de Vries et al. 2012; Scherr and McNeely 2008).

Among the enormous variety of life forms in soil, anecic earthworms may be particularly important in ameliorating the effects on soil and plants of intense rains. These large-bodied, detritivorous invertebrates modify their habitat and that of other organisms including the availability of resources (e.g., nutrients, rooting space), thus acting as ecosystem engineers (Jones et al. 1994). In particular, they dig vertical burrows that are connected to the soil surface and can act as preferential pathways for water flow and gas diffusivity (Edwards et al. 1990; Capowiez et al. 2009; Clements et al. 1991; Spurgeon et al. 2013). Such burrows are considered semipermanent structures, since they can exist beyond the individual that produced them (Shipitalo et al. 2004). Once abandoned, they are often reutilized by other earthworm individuals or colonized by plant roots (Nuutinen 2011). Where anecic earthworms occur, their burrows make a major contribution to soil macroporosity, as suggested by correlations between the density of earthworms and macropores (Francis and Fraser 1998; Lamandé et al. 2011). The role of these macropores to downward water flow may be relatively small under moderate soil moisture conditions (though not necessarily negligible - Nimmo 2012), but becomes more important as the soil approaches water-saturated conditions (Pitkänen and Nuutinen 1998). In fact, Spurgeon et al. (2013) showed that across several studies the biomass of anecic earthworms was positively correlated to water infiltration even after accounting for the role of tillage and soil type. Moreover, anecic earthworms promote plant growth through mechanisms other than burrowing, for instance by increasing $\mathrm{N}$ mineralization from plant residues and stimulating soil microbial activity (van Groenigen et al. 2014). Therefore, earthworms could sustain plant growth against intense rainfall disturbance by making macropores and thus enhancing the ability of the soil to take in water, as well as through positive effects on soil $\mathrm{N}$ availability and microbial communities. Such mechanisms are difficult to disentangle, as soil physical and biochemical changes due to earthworm activity are intrinsically interrelated.

In this study, we tested whether anecic earthworms can indeed ameliorate the detrimental effects of intense rains on soil and plants. To our knowledge this hypothesis has not been tested experimentally, although Chaudhry et al. (1987) found that under very wet soil conditions in a barley field earthworms improved drainage and oxygen diffusion rate, and as a result promoted the establishment of barley seedlings. No other study seems to have demonstrated a link between direct effects of earthworms on water infiltration and lagged (i.e., delayed) effects that may become apparent days or weeks after the disturbance, such as enhanced plant growth.

We performed a field experiment under ryegrass monocultures to test whether the presence of the anecic earthworm Lumbricus terrestris modulates the response of soil and plants to intense rain events. We hypothesised that earthworm presence would counteract the disturbance caused by the intense rainfall: (1) in the short term of hours to days by increasing soil intake of excess surface water; and (2) over a longer term (1 month) by offsetting disturbance-driven reduction of plant growth.

\section{Materials and methods}

Study site and experimental design

The study was performed from November 2013 to July 2014 in a long-term conventionally managed arable field, with a loamy-sandy soil of $\mathrm{pH} 5.5$ and organic matter content of $2 \%$, located in Wageningen University Droevendaal farm, in the Netherlands 
$\left(51^{\circ} 59^{\prime} 20.60^{\prime \prime} \mathrm{N}, 5^{\circ} 38^{\prime} 59.51^{\prime \prime} \mathrm{E}\right)$. The field had been cultivated with wheat but had no standing crop when it was last ploughed, to $25 \mathrm{~cm}$ depth, in November 2013. Previous field measurements showed that anecic earthworms were absent from the field, and no signs of their presence (such as surface casts or middens) were detected before ploughing.

On 22 November 2013, 28 mesocosms were established by inserting PVC cylinders $(30 \mathrm{~cm}$ diameter, $40 \mathrm{~cm}$ high) into undisturbed soil to a depth of $30 \mathrm{~cm}$, spaced $2 \mathrm{~m}$ apart in a regular grid $(7 \times 4)$. The distance between mesocosms, and the PVC enclosures, ensured independence of replicates. Within each grid row, mesocosms were randomly assigned to four treatments, i.e., two precipitation regimes crossed with two earthworm levels in a factorial design: with experimental intense rain events $(+\mathrm{R})$ or without $(-\mathrm{R})$, and with introduced $L$. terrestris $(+\mathrm{L})$ or without $(-\mathrm{L})$. More replicates were given to the two $+\mathrm{L}$ treatments to assess earthworm survival during the experiment. Thus, final sample size was $n=7$ for $+\mathrm{R}+\mathrm{L}$ and $-\mathrm{R}+\mathrm{L}$, and $n=5$ for $+\mathrm{R}-\mathrm{L}$ and $\mathrm{R}-\mathrm{L}$; the remaining four mesocosms were used to test the rainfall simulation methods before the main experiment.

One week after field installation, adult $L$. terrestris purchased from a commercial supplier were added, with four individuals in each $+\mathrm{L}(18.9 \pm 0.5 \mathrm{~g}$ S.E. fresh weight per mesocosm, equivalent to $270 \mathrm{~g} \mathrm{~m}^{-2}$ ). Velcro strips were glued to the inner edge of the mesocosms to prevent escape (Lubbers and van Groenigen 2013); escape belowground was possible but unlikely, as L. terrestris mostly digs vertically and disperses over the soil surface (Mather and Christensen 1988). To provide food and shelter, a mixture of Acer spp. and Fraxinus excelsior leaf litter (collected in November 2013) from a nearby forest floor and thoroughly mixed) was placed on the soil surface in all mesocosms ( $54 \pm 1 \mathrm{~g}$ dry weight each). The mesocosms were left in situ until March 2014 to allow earthworms to acclimatise and make burrows.

The remaining leaf litter was removed early in March 2014, and semi-liquid cattle manure (in dry matter: $5.0 \% \mathrm{~N}, 2.2 \% \mathrm{P}_{2} \mathrm{O}_{5}, 7.1 \% \mathrm{~K}_{2} \mathrm{O}$, dry matter content $20 \%)$ was applied $(20 \pm 1 \mathrm{~g}$ dry weight per mesocosm, equivalent to $140 \mathrm{~kg} \mathrm{~N} \mathrm{ha}^{-1}$ ). This was done more than 1 month before seeding, to ensure that the plants would not be N-limited during the experiment, allowing natural incorporation into soil through rainfall and activity of resident invertebrates in all mesocosms.

In the last week of March, access tubes for the insertion of a time domain reflectometry (TDR) moisture probe (TRIME T3, IMKO GmbH, Ettlingen, Germany) were installed outside six randomly chosen mesocosms $(n=3$ each for $+\mathrm{R}+\mathrm{L}$ and $+\mathrm{R}-\mathrm{L})$. The tubes were inserted outside the mesocosms at an angle of $55^{\circ}$ to the soil surface, so that the probe would measure soil moisture directly below the cylinders at $35 \mathrm{~cm}$ soil profile depth, without disrupting the soil above. On 24 April 2014, ryegrass (Lolium multiflorum var. Sultano) was seeded in all mesocosms (2.5 g seeds each). Mesocosms were inspected twice a week, and any weed seedlings growing inside or $\leq 0.5 \mathrm{~m}$ around were removed manually.

\section{Rainfall manipulation}

In addition to natural rainfall, all mesocosms received water through experimental irrigation, applied manually with a horticultural watering can with rose from a fixed height $(50 \mathrm{~cm})$. The cumulative amount was the same for all treatments, but the number and intensity of artificial rain events differed as follows: two intense showers, each equivalent to $36 \mathrm{~mm}$, were simulated in $+\mathrm{R}$, whereas the same total was spread over ten small events in -R (Fig. 1). The latter events were not intense enough to cause ponding on the soil surface. Natural daily rainfall of $36 \mathrm{~mm}$ or more occurred 22 times during the previous 30 years in Wageningen; in comparison, events of $34 \mathrm{~mm}$ or more are expected to increase in frequency by $6 \%$ in the Netherlands by the year 2100 , although there are large uncertainties in the estimate (Wijngaard et al. 2005). The first intense rain was simulated on 28 April 2014, when ryegrass seedlings started to emerge, and the second on 12 June. All mesocosms were covered with transparent plastic when very intense or prolonged rains were forecast (on 9 and 12 May, 5 June, and 22 July 2014). Taking into account both natural and simulated rains, and excluding rains during covering, total rainfall during the experiment was approximately $520 \mathrm{~mm}$ (14\% of which was artificial), close to the average for the period throughout the previous 30 years $(551 \mathrm{~mm})$. All precipitation data were obtained from the Royal Dutch Meteorological Institute (http:// www.knmi.nl/klimatologie/monv/reeksen/select_rr.html, weather station "Wageningen (Pd)", $51^{\circ} 58^{\prime} 00^{\prime \prime} \mathrm{N}, 05^{\circ} 39^{\prime}$ $\left.00^{\prime \prime} \mathrm{E}\right)$.

Data collection

During the intense rain events, the duration of waterlogging aboveground (that is, the time it took for 
Fig. 1 Weekly rainfall during the experiment, from the week before seeding to the second plant biomass collection, under two experimental precipitation regimes. The grey part of each bar shows the artificial rain that was provided to the mesocosms, either as ten moderate events $(-\mathrm{R})$ or as two intense events $(+\mathrm{R}$, identified with arrows). The dashed lines show the average weekly rainfall, which was the same in the two regimes

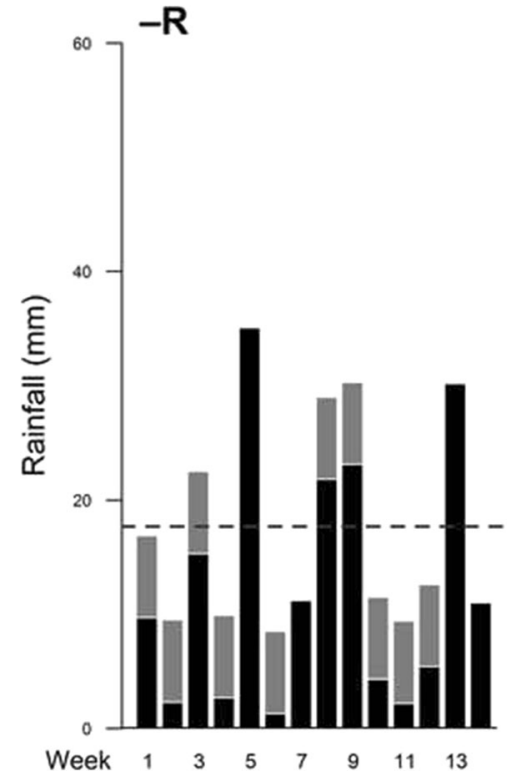

water ponding on the soil surface to disappear) was recorded in each $+\mathrm{R}$ mesocosm. After 3 and $24 \mathrm{~h}$, soil moisture (vol. \%) at $35 \mathrm{~cm}$ depth below three $+\mathrm{R}+\mathrm{L}$ and three $+\mathrm{R}-\mathrm{L}$ mesocosms was measured with the TDR probe. On 2 June, 1 month after the first $+\mathrm{R}$ event, ryegrass shoots were cut at $5 \mathrm{~cm}$ height (not at ground level to avoid overly destructive harvesting), oven-dried at $50{ }^{\circ} \mathrm{C}$ for $72 \mathrm{~h}$, and weighed $(+\mathrm{R}+\mathrm{L}$ and $-\mathrm{R}+\mathrm{L}, n=7$ each; $+\mathrm{R}-\mathrm{L}$ and $-\mathrm{R}-\mathrm{L}, n=5$ each). Three days after the first ryegrass sampling, $0.2 \%$ allyl isothiocyanate (AITC) was applied to two randomly chosen $+\mathrm{L}$ mesocosms (one $+\mathrm{R}$ and one $-\mathrm{R}$ ) to extract earthworms and gauge the survival rate. In these mesocosms, earthworm abundance had decreased by $50 \%$, and total biomass by $35 \%$. These mesocosms were excluded from further analyses.

On 10 July 2014, 1 month after the second +R event, all ryegrass biomass aboveground was harvested. A week later, earthworms were extracted with AITC $(+\mathrm{R}+\mathrm{L}$ and $-\mathrm{R}+\mathrm{L}, n=6$ each). AITC was also applied to the $-\mathrm{L}$ mesocosms to ensure that they were earthworm-free and to avoid biases in the subsequent analyses $(+\mathrm{R}-\mathrm{L}$ and $-\mathrm{R}-$ $\mathrm{L}, n=5$ each). Earthworms were confirmed as L. terrestris and weighed. On 23 July, the mesocosms were unearthed and carefully transported to a cold room $\left(4{ }^{\circ} \mathrm{C}\right)$. Over the next week, numbers of burrow openings and earthworm casts on the soil surface were recorded. Then, the outer cylinders were removed, and horizontal soil sections were cut at three depths $(10,20$ and $30 \mathrm{~cm})$. Visible macropores at the surface of each section were counted, and their vertical continuity was assumed if they were positioned on top of each other. The soil was subsequently handsorted to collect earthworms. Sub-samples of the ovendried plant material were analysed for $\mathrm{C}$ and $\mathrm{N}$ concentrations with an elemental analyser (LECO TruSpec, St. Joseph, MI, USA), and ryegrass C:N ratios were calculated to assess whether earthworms and/or rainfall regime affected $\mathrm{N}$ uptake in shoots (e.g., $\mathrm{N}$ losses by leaching through macropores during the intense rainfall might have been reflected in increased plant $\mathrm{C}: \mathrm{N}$ ratio in the $+\mathrm{L}+\mathrm{R}$ treatments, in addition to or instead of reduced plant growth and $\mathrm{N}$ mineralization).

Statistical analyses

The interactive effects of precipitation regime and earthworm presence on plants were assessed in linear models with a normal distribution, using ryegrass aboveground biomass ( $\mathrm{g}$ dry weight) or $\mathrm{C}: \mathrm{N}$ ratio as response variable and treatment as explanatory variable, separately for the two harvests. The effects of precipitation regime on density (per $\mathrm{m}^{2}$ ) of continuous macropores and earthworm biomass $(+\mathrm{L}$ only) and the effects of earthworm presence on waterlogging duration $(+R$ only) were assessed in linear models. The effects of precipitation regime on the number of earthworms retrieved at the end were assessed in generalized linear models (GLM), with a Poisson distribution and a log link function. Treatment statistical significance was assessed with F-tests (linear 
models with normal distribution) or $\chi^{2}$ tests (Poisson GLM). Means and standard errors were estimated from the models, together with associated t-tests and p-values to compare the treatments; $p$-value adjustments to avoid inflation of type I error rate (e.g., Tukey HSD test) were considered unnecessary, given the low number of pairwise comparisons (max. 6). Model distributional and variance assumptions were checked by visual inspection of the residuals (Zuur et al. 2010 and references therein). If needed to avoid heteroskedasticity, a special variance structure was used to allow a different variance in each treatment (R function 'varIdent', Pinheiro et al. 2014).

Correlations between earthworms retrieved at the end of the experiment (either as abundance or biomass) and final plant growth, and between earthworms and macropores, were tested using Spearman rank-order correlation $\left(\mathrm{r}_{\mathrm{s}}\right)$. We calculated means and standard errors of soil moisture at $35 \mathrm{~cm}$ depth, but refrained from testing treatment effects, as those data were only available for six mesocosm units ( $n=3$ per treatment), and we only interpreted them tentatively in the light of other, more robust data (e.g., on macropores). All statistical analyses were performed in R 3.1.0 (R Development Core Team 2014). Results are presented as mean \pm standard error.

\section{Results}

Plant response to intense rain and earthworm presence

One month after the first intense rain event (Fig. 2a), aboveground plant biomass was lower in $+\mathrm{R}$ than in $-\mathrm{R}$ treatments (on average $-17 \%$ ), but the effect depended on earthworm presence (rainfall $\times$ earthworm interaction, Table 1). L. terrestris increased plant growth, with grass shoot biomass being $23 \%$ larger in $+\mathrm{L}$ than in $-\mathrm{L}$, an effect mainly driven by the difference between treatments $+\mathrm{R}-\mathrm{L}$ and $-\mathrm{R}+\mathrm{L}(5.60 \pm 1.08$ vs. $8.88 \pm 0.69 \mathrm{~g}, p=$ $0.006)$. Plant biomass in $+\mathrm{R}-\mathrm{L}$ was also less than in $+\mathrm{R}+$ $\mathrm{L}(7.55 \pm 0.98 \mathrm{~g})$, although not significantly at the $5 \%$ probability level $(p=0.08)$, whereas there was more overlap between $-\mathrm{R}+\mathrm{L}$ and $-\mathrm{R}-\mathrm{L}(p=0.11)$.

The ameliorating effects of earthworms on plant growth were more evident after the second event (Fig. 2b): intense rainfall reduced plant growth only in the absence of $L$. terrestris (rainfall $\times$ earthworm interaction, Table 1). Grass biomass in $+\mathrm{R}-\mathrm{L}(10.07 \pm 1.14 \mathrm{~g})$ was significantly smaller than in $+\mathrm{R}+\mathrm{L}(12.45 \pm 0.77 \mathrm{~g}$, $p=0.04)$ and $-\mathrm{R}+\mathrm{L}(13.45 \pm 1.08 \mathrm{~g}, p=0.008)$, while there was no difference between $+\mathrm{R}+\mathrm{L}$ and $-\mathrm{R}+\mathrm{L}(p=$ 0.41).

Plant $\mathrm{C}: \mathrm{N}$ ratio was not affected by precipitation regime or earthworm presence in either sampling $(p>0.10)$. The ratio was much higher in the second sampling (ranging from 28.9 to 48.8 ) than in the first (ranging from 20.1 to 27.9), a change driven by a strong decrease in $\mathrm{N}$ concentration (from 18.0 to $10.9 \mathrm{~g} \mathrm{~kg}^{-1}$ on average) as the $\mathrm{N}$-rich seedlings developed into maturing swards.

\section{Earthworm responses to intense rain}

Of the inoculated L. terrestris, $40 \%$ were retrieved at the end of the experiment. No other earthworm species were found except sporadic individuals of Aporrectodea caliginosa (small soil-feeding earthworms with body mass $<0.5 \mathrm{~g}$ ); at higher densities these earthworms could have affected soil structure and plants, but in this study they were too rare to have any substantial effect. Plant biomass in $+\mathrm{L}$ mesocosms was not correlated to earthworm abundance $\left(\mathrm{r}_{\mathrm{s}}=0.14, p=0.66\right)$, nor to biomass $\left(\mathrm{r}_{\mathrm{s}}=0.16, p=0.61\right)$, suggesting that the positive effect of $L$. terrestris was not an artefact induced by earthworm mortality, i.e., it was not an unwanted "fertilizer" effect of dead individuals. In fact, at the end of the experiment there was no difference between $+\mathrm{R}+\mathrm{L}$ and $-\mathrm{R}+\mathrm{L}$ with respect to earthworm numbers or biomass (Table 1), which entails a corresponding lack of difference in the small amounts of $\mathrm{N}$ released from the dead earthworms (mean per mesocosm $0.12 \mathrm{~g}$ in $-\mathrm{R}+\mathrm{L}$ vs. $0.10 \mathrm{~g}$ in $+\mathrm{R}+$ $\mathrm{L}$, estimated based on earthworm body $\mathrm{N}$ content of $10.1 \%$ [Schmidt 1999]).

Earthworm effects on soil structure and moisture

Continuous macropores were found only in $+\mathrm{L}$ mesocosms, and their size and shape corresponded to L. terrestris burrows. They were 2.4 times more abundant in $+\mathrm{R}+\mathrm{L}$ than in $-\mathrm{R}+\mathrm{L}$ (Table 1 ), and ranged from none to three per mesocosm. There was no significant correlation between the number of macropores and the abundance $\left(\mathrm{r}_{\mathrm{s}}=0.36, p=0.51\right)$ or the biomass $\left(\mathrm{r}_{\mathrm{s}}=0.20\right.$, $p=0.25$ ) of earthworms at the end of the experiment. Although some soil detachment from the cylinder walls was detected, earthworm activity was not concentrated 


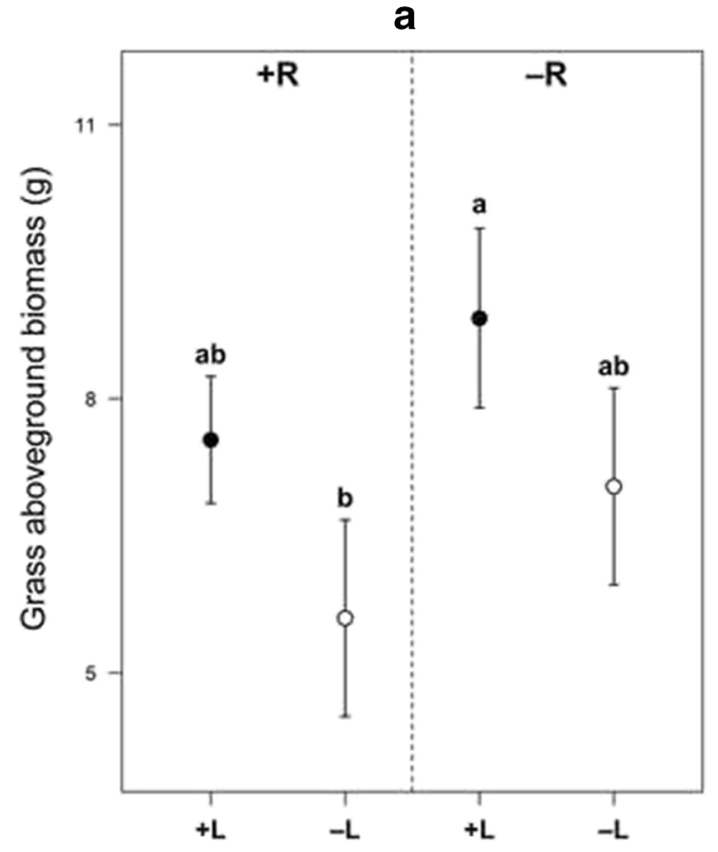

Fig. 2 Means and standard errors of ryegrass (L. multiflorum) shoot biomass ( $g$ dry weight per microcosm) in mesocosms with the anecic earthworm Lumbricus terrestris $(+\mathrm{L}$, black circles) or without $(-\mathrm{L}$, white circles), under two precipitation regimes $(+\mathrm{R}$ and $-\mathrm{R}$, see Fig. 1). Biomass was measured (a) 1 month after the b

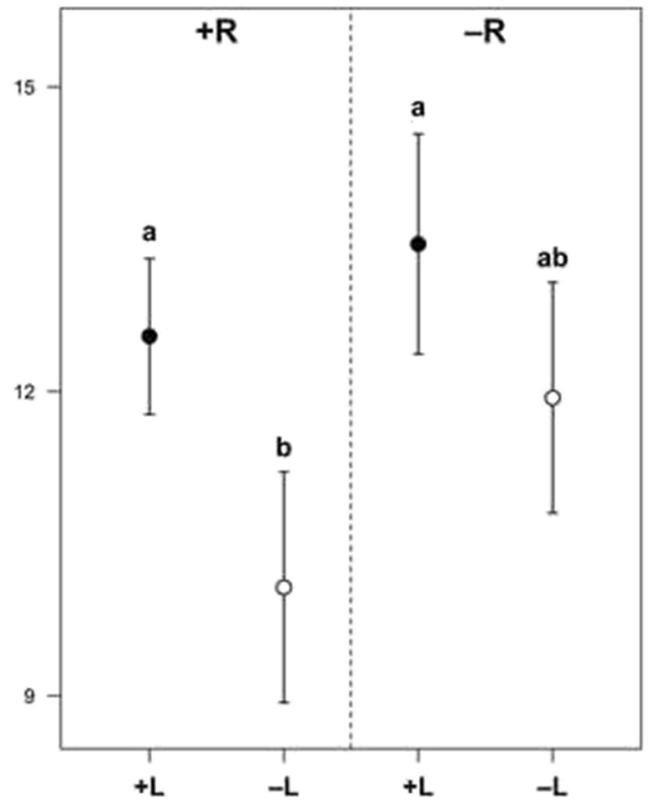

first intense rain event (in the $+\mathrm{R}$ mesocosms), and (b) 1 month after the second event. Different small letters above the error bars mark differences between treatments that were statistically significant at the level of $p=0.05$, as tested by linear models, separately in (a) and (b)

Table 1 Summary of outcomes of F-tests of general linear models and $\chi^{2}$ test of a Poisson generalized linear model

Waterlogging duration aboveground (surface ponding) induced by simulated intense rainfall

\section{Source of variation}

First event

Second event

\section{F}

0.13

0.19
$\mathrm{P}$

0.72

0.68
Treatments (n)

$+\mathrm{R}+\mathrm{L}(7),+\mathrm{R}-\mathrm{L}(5)$

$+\mathrm{R}+\mathrm{L}(6),+\mathrm{R}-\mathrm{L}(5)$

Plant shoot biomass 1 month after the simulated intense rain events

\section{First event}

\section{Source of variation}

Rainfall $\times$ Earthworm interaction

Rainfall regime

Earthworm presence

Second event

Rainfall $\times$ Earthworm interaction

Rainfall regime

Earthworm presence

\section{F}

3.19

3.53

6.52

3.11

2.92

6.36

\section{$\mathrm{P}$}

0.04

0.08

0.02

0.05

0.10

0.02

Earthworm response at the end of the experiment

Source of variation

Survival

Rainfall regime

F

0.47

$\mathrm{P}$

0.49

$2.31 \quad 0.16$

Biomass

Rainfall regime

Number of vertical macropores found at the end of the experiment

Macropores $^{\mathrm{a}}$

Source of variation

$\chi^{2}$

Rainfall regime

$\mathrm{P}$

0.02
Treatments (n)

$+\mathrm{R}+\mathrm{L}(7),+\mathrm{R}-\mathrm{L}(5),-\mathrm{R}+\mathrm{L}(7),-\mathrm{R}-\mathrm{L}(5)$

$+\mathrm{R}+\mathrm{L}(6),+\mathrm{R}-\mathrm{L}(5),-\mathrm{R}+\mathrm{L}(6),-\mathrm{R}-\mathrm{L}(5)$

The rightmost column shows the treatments being compared for each model and their sample size (n)

${ }^{\text {a }}$ No vertical macropores were found in $-\mathrm{L}$ mesocosms 
along the walls, as only $13.8 \%$ of the burrows were visible at the mesocosm perimeter.

After the first intense rain, visual aboveground waterlogging duration ranged from 60 to $605 \mathrm{~s}$, with no consistent difference between $+\mathrm{R}+\mathrm{L}$ and $+\mathrm{R}-\mathrm{L}$ (144 \pm 47 vs. $182 \pm 106 \mathrm{~s}$, Table 1$)$. The same was found after the second intense rain event, with a duration of 45 $312 \mathrm{~s}$, and no effect of earthworm presence $(+\mathrm{R}+\mathrm{L} 117 \pm$ $30 \mathrm{~s},+\mathrm{R}-\mathrm{L} 142 \pm 50 \mathrm{~s}$, Table 1). On the other hand, soil moisture at $35 \mathrm{~cm}$ depth was the same in the two treatments $3 \mathrm{~h}$ after the first rain event $(18.9 \pm 0.7$ and $18.0 \pm$ $3.5 \%, n=3$ each), whereas $24 \mathrm{~h}$ later it had decreased in + $\mathrm{R}+\mathrm{L}(15.3 \pm 1.9 \%)$ but not in $+\mathrm{R}-\mathrm{L}(18.8 \pm 2.6 \%)$, suggesting that earthworm presence triggered a faster decrease in soil moisture (Fig. 4). This would be consistent with the presence of macropores only in $+\mathrm{L}$ mesocosms (see above), but is nonetheless only a tentative explanation, as no statistical inference could be made on soil moisture data.

\section{Discussion}

Earthworms promoted plant growth and modified soil physical structure

We showed that the anecic earthworm $L$. terrestris can buffer the soil-plant system against the effects of intense rain events. Earthworms counteracted the adverse effects of intense precipitation on model ryegrass mesocosms, partially (first $+\mathrm{R}$ event, Fig. 2a) or fully (second $+\mathrm{R}$ event, Fig. 2b) offsetting rain-induced reduction of aboveground plant biomass. Soil moisture data from $35 \mathrm{~cm}$ depth suggest that water flow belowground was improved by earthworm presence after $24 \mathrm{~h}$ (Fig. 4). This interpretation should be taken as tentative, because soil moisture was measured only under six mesocosm units, but is nonetheless consistent with the presence of macropores only in mesocosms with added L. terrestris $(+\mathrm{L})$. We recognize that our irrigation technique did not realistically simulate the small-scale impact of raindrops, but we argue that it was adequate for the aims of the study.

Waterlogging duration at the soil surface was not clearly affected by earthworm presence. A reason could be that the water input was not enough to approximate saturation. It should be noted, however, that water infiltration is highly heterogeneous in space (Hassler et al. 2014), and that the experiment was performed in intact soil, rather than in a homogenised substrate. Water infiltration may indeed be unpredictable even under highly controlled conditions: for instance, in a greenhouse experiment that simulated a heavy rainfall event similar to ours $(40 \mathrm{~mm})$, anecic earthworms increased water infiltration (Zaller et al. 2011), but the effect was not repeatable in a subsequent experiment with similar methodology (Zaller et al. 2014).

Only $40 \%$ of the inoculated earthworms were recovered at the end of the experiment, indicating mortality, inefficiency of AITC extraction from deep soil, or (though less likely) escape despite the Velcro strips. Escape belowground cannot be excluded either, although it would imply that the earthworms burrowed not only vertically but also horizontally below the mesocosms, and no signs of such activity were observed inside the mesocosms. Notably, vertical macropores were found also in $+\mathrm{L}$ mesocosms where no earthworm was retrieved, indicating that the missing earthworms had been active during the experiment. Those macropores were considered burrows formed by L. terrestris, as no such structures were found in any $\mathrm{L}$ mesocosm. In $+\mathrm{L}$ there was no correlation between number of burrows and earthworm abundance or biomass, suggesting that some earthworms shared a burrow.

There were on average more than twice as many burrows in the intense rain regime as in the control regime, despite no corresponding difference in the number of earthworms retrieved at the end of the experiment (Fig. 3). Assuming that any missing individuals had died during the experiment, this indicates that the earthworms were digging more burrows under the intense rain regime. This was an unexpected and novel finding: although earthworms are known to react to intense rainfall by obstructing their burrows temporarily (Ela et al. 1992), we are unaware of any previous study in field conditions that showed increased burrowing behaviour in response to increased soil moisture or intense rain. Such increased burrowing activity could be due to a facilitative effect of intense rainfall (i.e., conditions were favourable for digging), or on the contrary it could indicate that the earthworms were stressed by the disturbance and tried to escape or improve their habitat conditions. Regarding L. terrestris survival and growth, it has been shown that high soil moisture may be favourable (Berry and Jordan 2001), while prolonged flooding is detrimental (Fournier et al. 2012). 
Fig. 3 Percentage of the introduced $L$. terrestris individuals found at the end of the experiment (triangles), and density of continuous vertical macropores (circles) in the two precipitation regimes $(+\mathrm{L}$ treatment only). The $p$-values refer to the comparison between the two R regimes, and are based on a Poisson GLM and a general linear model, respectively

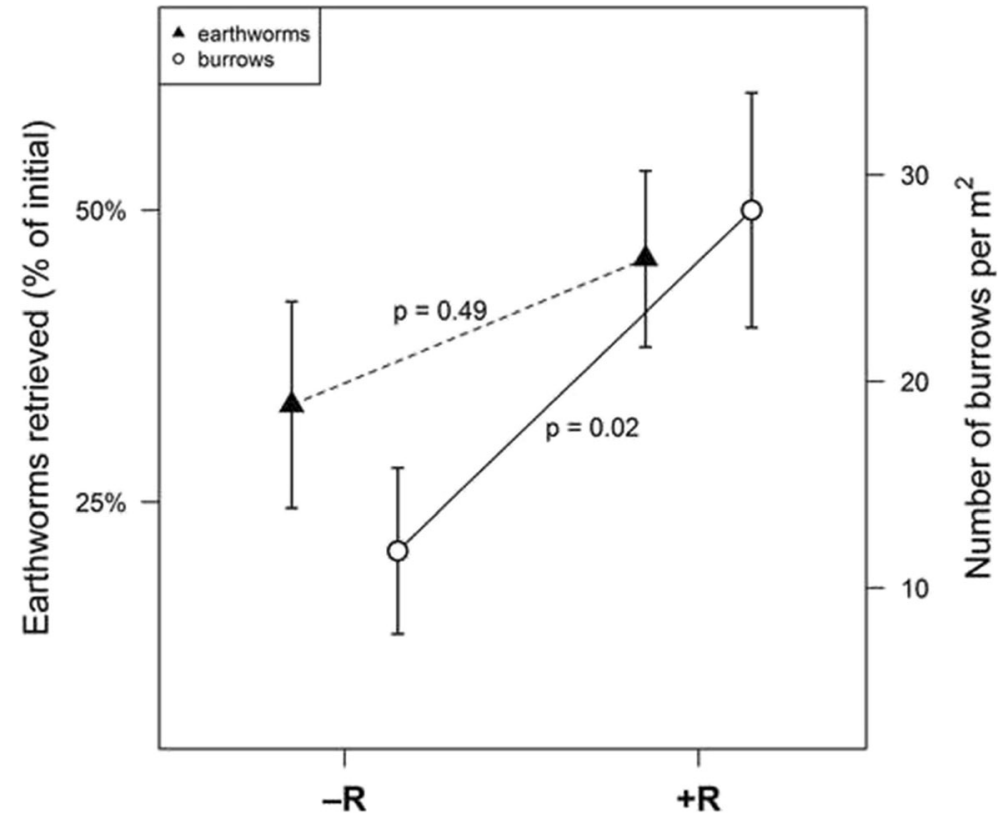

How did the earthworms counteract negative effects of rain on plants?

The supposedly faster decrease of soil moisture after the intense rain event in the presence of earthworms (Fig. 4), coupled with the lack of vertical macropores in earthwormfree mesocosms, suggests that $L$. terrestris counteracted the rain-induced disturbance of plant growth by enhancing water drainage through burrow formation. Water flow in macropores is considerably faster than in matrix soil (Jarvis 2007), and early experimental work showed that earthworm presence can prevent waterlogging (Guild 1955). On the other hand, it is possible that the intense rainfall disturbance did not induce anoxia in the rhizosphere, as waterlogging duration aboveground was not affected by earthworm presence.
Therefore, other mechanisms not necessarily related to physical soil structure might also have been involved, or even may have dominated. In particular, earthworms may have improved the availability of $\mathrm{N}$ to plants (van Groenigen et al. 2014), for instance by incorporating the surface-applied manure into the rhizosphere and releasing $\mathrm{N}$ through mucus and casts, stimulating microbial activity and turnover (Postma-Blaauw et al. 2006). It is possible that earthworm-enhanced $\mathrm{N}$ availability to plants more than compensated for any leaching induced by intense rainfall; but $L$. terrestris usually increases $\mathrm{N}$ losses through leaching (Domínguez et al. 2004; Costello and Lamberti 2008; Zaller et al. 2011). To ensure that the plants would not be N-limited during the experiment, we had fertilized all the mesocosms with manure more than 1 month before seeding. Although plant $\mathrm{C}: \mathrm{N}$ ratio
Fig. 4 Soil moisture (vol. \%) $35 \mathrm{~cm}$ below a subset of the $+\mathrm{R}$ mesocosms $(n=3+\mathrm{R}+\mathrm{L}, n=3$ $+\mathrm{R}-\mathrm{L}$ ), as measured with a TDR probe $3 \mathrm{~h}$ (left) and $24 \mathrm{~h}$ (right) after the first rain event. The thick lines in the boxes show the medians and the dots show the means, while the bars outside the boxes delimit the interquartile range
3 hours after $+R$ event

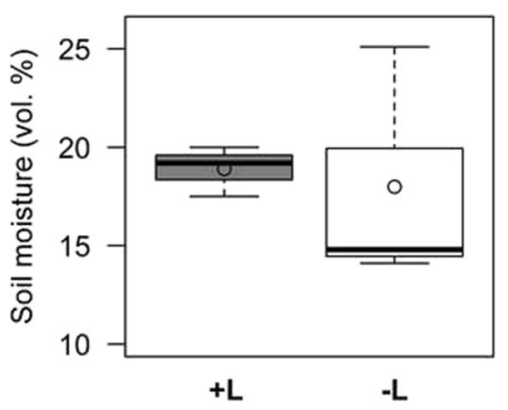

24 hours after $+R$ event

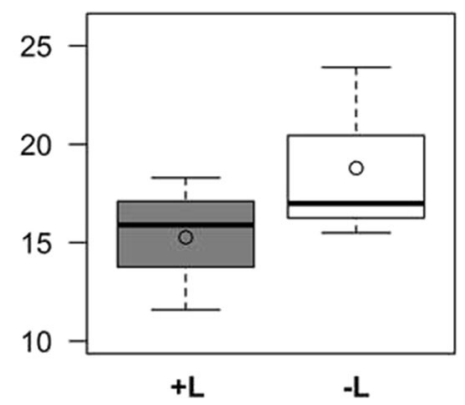


increased with time (from 28.9 to 48.8), precipitation regime and earthworm presence did not induce variation in C:N ratio or $\mathrm{N}$ concentration. We emphasize that the positive impact of earthworms on plant growth was not an artifact caused by a fertilizing effect of dead individuals: plant biomass was not larger in mesocosms with higher earthworm mortality, nor was there a (negative) correlation with earthworm numbers at the end of the experiment. We did not examine the response of the plants belowground, as earthworms usually do not alter proportional biomass allocation in shoots vs. roots (van Groenigen et al. 2014), but it should be noted that roots themselves can affect water flow in soil.

It is difficult to disentangle physical and biochemical effects of anecic earthworms on plants, as they are bound to co-occur. However, the positive effects of earthworms on plant growth through enhanced nutrient cycling are expected to decrease in importance with increasing soil fertility (van Groenigen et al. 2014), although this is not always the case (Laossi et al. 2010). Therefore, to determine whether anecic earthworms counteract the effects of intense rains on plants through burrow formation, enhanced nutrient availability, or yet some other mechanism (e.g., release of hormone-like substances - Puga-Freitas et al. 2012), future studies could compare model systems with the same earthworm and plant species but different soil fertility conditions. A complementary approach could be to compare treatments with anecic earthworms to corresponding treatments with the burrows but without earthworms. Earthworm-free burrows may be obtained through non-destructive earthworm removal, or by artificial construction. The first technique would ensure realism, though perhaps at the cost of non-target legacy effects, caused by the mucus secreted and the organic detritus incorporated in the burrows. However, such biochemical effects are short-lived in the absence of earthworms (Andriuzzi et al. 2013), while legacy effects in terms of soil structure are longer-lived, since anecic earthworm burrows can outlast their makers (Shipitalo et al. 2004). Future experiments should also attempt to investigate root growth and development in addition to plant shoots.

Implications for future studies

Our experiment can be considered a proof-of-concept study, as it involved a simplified community with a single plant species, one earthworm species, a single soil type, comparing just two regimes of precipitation. The same grass species might have responded differently to equally intense rains with different timing, or in a different type of soil. We also recognize that, since our grass swards were young, plant root effects on soil structure may not have fully established yet, possibly leading to an overestimation of the earthworm effect. On the other hand, if a population of anecic earthworms had been present for a longer time than the few months between mesocosm establishment and experimental operations, there could have been more and deeper burrows, possibly resulting in a stronger effect.

Our results are consistent with a large body of literature on the positive effects of anecic earthworms on soil hydrological conductivity and plant growth (Spurgeon et al. 2013; van Groenigen et al. 2014). Nevertheless, caution is needed in extrapolating our results based on L. terrestris to other anecic species. While species in this functional group are presumed to have the same effects on soil macroporosity and water flow, the assumption is largely untested. Distinct anecic earthworm species do differ in burrowing activity and burrow morphology. For example, using X-ray tomography on re-packed soil cores, Bastardie et al. (2005) found that two so-called anecic species did not actually re-use their burrows, in contrast to L. terrestris. Furthermore, it has long been known that anecic earthworms may obstruct the openings of their burrows with casts and middens (Darwin 1881), but not all species do this under the same conditions. For instance, comparing the burrow systems of L. badensis and L. polyphemus, Lamparski et al. (1987) found that only the latter protects the surface openings with middens, making its galleries less susceptible to drying out. Finally, some species (e.g., Aporrectodea longa) usually aestivate in summer even if temperature and moisture conditions are favourable, while others (e.g., L. terrestris) are active year-round as long as the soil does not freeze or dry out (Lee 1985). Knowledge of the ecology of species is therefore essential to predict their responses to extreme weather events.

\section{Conclusions}

We provide the first experimental evidence that anecic earthworms can counteract the effects of intense rain events on soil and plants. Moreover, we found that earthworms produced more burrows under an intense 
rain regime, suggesting that changing rainfall patterns could modify earthworm burrowing behaviour. As some of the strongest ecological and agronomic effects of climate change will occur through pulse events, rather than altered average trends, this role of earthworms needs to be explored further. The combined findings of many previous studies on the generally positive effects of earthworms on plant growth and water flow in soil suggest that our results may apply to other soils and species, although experimental validation is needed. Our results point to soil structure modification by earthworms (i.e., macropore formation) as a mechanism behind this effect, but the contribution of other cooccurring mechanisms, such as enhanced nutrient availability to plants, needs to be elucidated. Moreover, potential trade-offs between contrasting earthworm effects should be investigated, for example increased nutrient leaching as a result of improved drainage.

Acknowledgments This study was financially supported by the European Commission within the EcoFINDERS project (FP7264465). We thank Ingrid Lubbers for information on the field site, Mart Ros for procuring the earthworms, Harm Bartholomeus for helping with preliminary remote sensing measurements, Piet Peters and Harm Boesveld for providing the TDR probe and access tubes, and the Unifarm staff for assistance with the practical work. We also thank Tom Bolger, Jan Willem van Groenigen, Sven Marhan and two anonymous reviewers for helpful comments on the manuscript.

Open Access This article is distributed under the terms of the Creative Commons Attribution 4.0 International License (http:// creativecommons.org/licenses/by/4.0/), which permits unrestricted use, distribution, and reproduction in any medium, provided you give appropriate credit to the original author(s) and the source, provide a link to the Creative Commons license, and indicate if changes were made.

\section{References}

Andriuzzi WS, Bolger T, Schmidt O (2013) The drilosphere concept: fine-scale incorporation of surface residue-derived $\mathrm{N}$ and $\mathrm{C}$ around natural Lumbricus terrestris burrows. Soil Biol Biochem 64:136-138

Bastardie F, Capowiez Y, Renault P, Cluzeau D (2005) A radiolabelled study of earthworm behaviour in artificial soil cores in term of ecological types. Biol Fertil Soils 41:320-327

Batey T (2009) Soil compaction and soil management - a review. Soil Use Manag 25:335-345

Beier C, Beierkuhnlein C, Wohlgemuth T, Penuelas J, Emmett B, Körner C, Boeck H, Christensen JH, Leuzinger S, Janssens IA (2012) Precipitation manipulation experiments - challenges and recommendations for the future. Ecol Lett 15: 899-911
Berry E, Jordan D (2001) Temperature and soil moisture content effects on the growth of Lumbricus terrestris (Oligochaeta: Lumbricidae) under laboratory conditions. Soil Biol Biochem 33:133-136

Brussaard L, de Ruiter PC, Brown GG (2007) Soil biodiversity for agricultural sustainability. Agric Ecosyst Environ 121:233-244

Cannell RQ, Belford RK, Gales K, Dennis CW, Prew RD (1980) Effects of waterlogging at different stages of development on the growth and yield of winter wheat. J Sci Food Agric 31: $117-132$

Cannell R, Belford R, Gales K, Thomson R, Webster C (1984) Effects of waterlogging and drought on winter wheat and winter barley grown on a clay and a sandy loam soil. Plant Soil 80:53-66

Capowiez Y, Cadoux S, Bouchant P, Ruy S, Estrade JR, Richard G, Boizard H (2009) The effect of tillage type and cropping system on earthworm communities, macroporosity and water infiltration. Soil Tillage Res 105:209-216

Chaudhry A, Baker C, Springett J (1987) Barley seedling establishment by direct drilling in a wet soil. 2. Effects of earthworms, residue and openers. Soil Tillage Res 9:123-133

Clements R, Murray P, Sturdy R (1991) The impact of 20 years' absence of earthworms and three levels of $\mathrm{N}$ fertilizer on a grassland soil environment. Agric Ecosyst Environ 36:75-85

Costello DM, Lamberti GA (2008) Non-native earthworms in riparian soils increase nitrogen flux into adjacent aquatic ecosystems. Oecologia 158:499-510

Darwin C (1881) The formation of vegetable mould, through the action of worms, with observations on their habits. J. Murray, London

de Vries FT, Liiri ME, Bjørnlund L, Bowker MA, Christensen S, Setälä HM, Bardgett RD (2012) Land use alters the resistance and resilience of soil food webs to drought. Nat Clim Chang 2:276-280

Domínguez J, Bohlen PJ, Parmelee RW (2004) Earthworms increase nitrogen leaching to greater soil depths in row crop agroecosystems. Ecosystems 7:672-685

Edwards W, Shipitalo M, Owens L, Norton L (1990) Effect of Lumbricus terrestris L. burrows on hydrology of continuous no-till corn fields. Geoderma 46:73-84

Ela SD, Gupta SC, Rawls WJ (1992) Macropore and surface seal interactions affecting water infiltration into soil. Soil Sci Soc Am J 56:714-721

Fournier B, Samaritani E, Shrestha J, Mitchell EA, Le Bayon R-C (2012) Patterns of earthworm communities and species traits in relation to the perturbation gradient of a restored floodplain. Appl Soil Ecol 59:87-95

Francis G, Fraser P (1998) The effects of three earthworm species on soil macroporosity and hydraulic conductivity. Appl Soil Ecol 10:11-19

Guild WJMCL (1955) Earthworms and soil structure. In: McE Kevan DK (ed) Soil zoology. Butterworths Sci. Publ, London, pp 83-98

Hassler S, Lark R, Zimmermann B, Elsenbeer H (2014) Which sampling design to monitor saturated hydraulic conductivity? Eur J Soil Sci 65:792-802

IPCC (2013) Climate change 2013: the physical science basis. Intergovernmental Panel on Climate Change, Working Group I Contribution to the IPCC Fifth Assessment Report. Cambridge University Press, New York, Accessed online at http://www.ipcc.ch/report/ar5/

Jarvis N (2007) A review of non-equilibrium water flow and solute transport in soil macropores: principles, controlling factors and consequences for water quality. Eur J Soil Sci 58:523-546 
Jentsch A, Kreyling J, Beierkuhnlein C (2007) A new generation of climate-change experiments: events, not trends. Front Ecol Environ 5:365-374

Jones CG, Lawton JH, Shachak M (1994) Organisms as ecosystem engineers. Oikos 69:373-386

Lamandé M, Labouriau R, Holmstrup M, Torp SB, Greve MH, Heckrath G, Iversen BV, De Jonge LW, Moldrup P, Jacobsen OH (2011) Density of macropores as related to soil and earthworm community parameters in cultivated grasslands. Geoderma 162:319-326

Lamparski F, Kobel-Lamparski A, Kaffenberger R (1987) The burrows of Lumbricus badensis and Lumbricus polyphemus. In: Bonvicini-Pagliai AM, Omodeo P (eds) On earthworms. Mucchi Editore, Modena, pp 131-140

Laossi K-R, Ginot A, Noguera DC, Blouin M, Barot S (2010) Earthworm effects on plant growth do not necessarily decrease with soil fertility. Plant Soil 328:109-118

Lee KE (1985) Earthworms: their ecology and relationships with soils and land use. Academic, Sydney

Lubbers IM, van Groenigen JW (2013) A simple and effective method to keep earthworms confined to open-top mesocosms. Appl Soil Ecol 64:190-193

Mather J, Christensen O (1988) Surface movements of earthworms in agricultural land. Pedobiologia 32:399-405

Nimmo JR (2012) Preferential flow occurs in unsaturated conditions. Hydrol Process 26:786-789

Nuutinen V (2011) The meek shall inherit the burrow: feedback in earthworm soil modification. In: Karaca A (ed.) Biology of earthworms. Springer

Pinheiro J, Bates D, DebRoy S, Sarkar D (2014) R Development Core Team. nlme: linear and nonlinear mixed effects models. $\mathrm{R}$ package version 3.1-117. R Foundation for Statistical Computing, Vienna

Pitkänen J, Nuutinen V (1998) Earthworm contribution to infiltration and surface runoff after 15 years of different soil management. Appl Soil Ecol 9:411-415

Postma-Blaauw MB, Bloem J, Faber JH, van Groenigen JW, de Goede RGM, Brussaard L (2006) Earthworm species composition affects the soil bacterial community and net nitrogen mineralization. Pedobiologia 50:243-256

Puga-Freitas R, Barot S, Taconnat L, Renou J-P, Blouin M (2012) Signal molecules mediate the impact of the earthworm Aporrectodea caliginosa on growth, development and defence of the plant Arabidopsis thaliana. PLoS ONE 7, e49504

R Development Core Team (2014) R: a language and environment for statistical computing. R Foundation for Statistical Computing, Vienna, http://www.R-project.org
Reyer CP, Leuzinger S, Rammig A, Wolf A, Bartholomeus RP, Bonfante A, de Lorenzi F, Dury M, Gloning P, Abou Jaoudé R (2013) A plant's perspective of extremes: terrestrial plant responses to changing climatic variability. Glob Chang Biol 19:75-89

Rosenzweig C, Tubiello FN, Goldberg R, Mills E, Bloomfield J (2002) Increased crop damage in the US from excess precipitation under climate change. Glob Environ Chang 12:197202

Sairam R, Kumutha D, Ezhilmathi K, Deshmukh P, Srivastava G (2008) Physiology and biochemistry of waterlogging tolerance in plants. Biol Plant 52:401-412

Scherr SJ, McNeely JA (2008) Biodiversity conservation and agricultural sustainability: towards a new paradigm of 'ecoagriculture'landscapes. Philos Trans R Soc B 363:477494

Schmidt O (1999) Intrapopulation variation in carbon and nitrogen stable isotope ratios in the earthworm Aporrectodea longa. Ecol Res 14:317-328

Setter T, Waters I (2003) Review of prospects for germplasm improvement for waterlogging tolerance in wheat, barley and oats. Plant Soil 253:1-34

Shipitalo MJ, Nuutinen V, Butt KR (2004) Interaction of earthworm burrows and cracks in a clayey, subsurface-drained, soil. Appl Soil Ecol 26:209-217

Spurgeon DJ, Keith AM, Schmidt O, Lammertsma DR, Faber JH (2013) Land-use and land-management change: relationships with earthworm and fungi communities and soil structural properties. BMC Ecol 13:46. doi:10.1186/1472-6785-13-46

van Groenigen JW, Lubbers IM, Vos H, Brown GG, de Deyn GB, van Groenigen KJ (2014) Earthworms increase plant production: a meta-analysis. Sci Rep 4:6365. doi:10.1038/ srep06365

Wijngaard JB, Kok M, Smits I, Talsma M (2005) Nieuwe statistiek voor extreme neerslag [In Dutch]. H2O 6:35-37

Zaller JG, Heigl F, Grabmaier A, Lichtenegger C, Piller K, Allabashi R, Frank T, Drapela T (2011) Earthwormmycorrhiza interactions can affect the diversity, structure and functioning of establishing model grassland communities. PLoS ONE 6, e29293

Zaller JG, Heigl F, Ruess L, Grabmaier A (2014) Glyphosate herbicide affects belowground interactions between earthworms and symbiotic mycorrhizal fungi in a model ecosystem. Sci Rep 4:5634. doi:10.1038/srep05634

Zuur AF, Leno EN, Elphick CS (2010) A protocol for data exploration to avoid common statistical problems. Methods Ecol Evol 1:3-14 